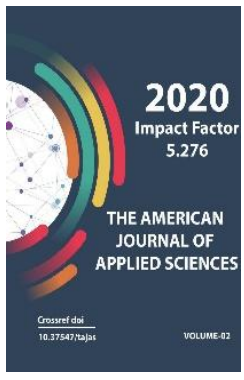

Journal Website: http://usajournalshub.c om/index,php/tajas

Copyright: Original content from this work may be used under the terms of the creative commons attributes 4.0 licence.

\section{The Study Of The Micronutrient Composition Of The Plant Capsella Bursa - Pastoris, Growing In Mountainous Areas}

\author{
Shaxriddin Shavkat ogli Juraev \\ National University Of Uzbekistan Named After Mirzo Ulugbek, Tashkent, Uzbekistan \\ Sokhiba Davlatbayevna Madrakhimova \\ National University Of Uzbekistan Named After Mirzo Ulugbek,Tashkent, Uzbekistan \\ Farrux Nozimovich Tashpulatov \\ Institute Of Bioorganic Chemistry, Academy Of Sciences Of The Republic Of Uzbekistan, \\ Tashkent, Uzbekistan \\ Raxmatilla Sulton ogli Esanov \\ Institute Of Bioorganic Chemistry, Academy Of Sciences Of The Republic Of Uzbekistan, \\ Tashkent, Uzbekistan \\ Alimjan Davlatbayevich Matchanov \\ Institute Of Bioorganic Chemistry, Academy Of Sciences Of The Republic Of Uzbekistan, \\ Tashkent, Uzbekistan
}

\title{
ABSTRACT
}

The quantitative content of water-soluble vitamins of the aerial part of the plant Capsella bursa was determined by high performance liquid chromatography (HPLC). Using the inductively coupled plasma mass spectrometry (ICP-MS) method, the quantitative content of vital macro- and microelements in the various vegetative organs of the Capsella bursa plant was determined

\section{KEYWORDS}

Shepherd's purse, vitamins, microelements, macroelements, HPLC, ICP/MS.

\section{INTRODUCTION}

Bleeding from various organs of a person is one of the main causes of traumatic injuries, ending in death. Despite the fact that bleeding and its consequences, as well as first aid methods have been studied since the inception of medicine, a number of issues of this problem still remain unresolved. In this case, much attention is paid to the problem of 
stopping bleeding, especially by surgeons, since it still limits the possibilities of the surgical method and can serve as the main cause of death of the patient.

In this relationship, the plant Capsella bursa, commonly known as a shepherd's bag, has unique properties, and is used as a hemostatic and antidiabetic agent, and as an antioxidant [1].

The shepherd's purse contains a large number of vitamins: B, C, provitamin A, gisopene ramnoglycoside, bursic acid, tannins, fumaric, malic and tartaric acids, choline, acetylcholine, triamines, flavanoids, isothiocinates, sulforaphanes, sesquilignan and phenol glycosides [2-7].

It is known that 11 mineral elements are indispensable components of human food. Deficiency of macro- and microelements can cause the development of a pathological process in the human body. So, Na cations are involved in maintaining acid-base balance and the osmotic pressure of extracellular fluids. $\mathrm{Ca}$ ions activate the action of many enzymes and promote blood coagulation. As part of a shepherd's bag, potassium and calcium are determined in significant quantities. In addition, the remaining macro- and micronutrients are also identified.

Therefore, the study of the microelement composition of medicinal plant materials is of particular relevance [8].

However, it should be noted that the macroand microelement composition of the Shepherd's bag plant is relatively little studied, especially growing in mountain and foothill areas.

But the basic hemostatic active principle of the Capsella bursa plant is still unclear.
Therefore, the study of the vitamin composition of vegetative organs, as well as macro-and microelement composition, is an urgent task.

The aim of this work was a comparative study of the chemical composition of the plant Capsella bursa growing on the plains and in the mountainous regions of the Republic of Uzbekistan.

For the study, dried aboveground parts of the plant Capsella bursa - pastoris growing in the mountainous regions of the Samarkand and Jizzakh regions of the Republic were used. A quantitative analysis of the composition of macro and microelements contained in the Capsella bursa plant was studied by inductively coupled plasma mass spectrometry (ICP-MS), since one of the most common methods for analyzing the elemental composition of medicinal plant materials is inductively coupled mass spectrometry plasma. [9].

\section{MATERIALS AND METHODS}

We used the method of extraction of watersoluble vitamins from the aerial parts of the plant with methanol, as well as with a mixture of ethanol: water (1:1), followed by filtration and evaporation of the organic part on a rotary evaporator. The residue was filtered and centrifuged for 7 minutes at $7000 \mathrm{rpm}$. The resulting solution was analyzed by high performance liquid chromatography (HPLC). Detection was carried out using a diode array detector (DAD) in the near ultraviolet region of the spectrum.

\section{Chromatographic analysis conditions:}

Mobile phase (gradient mode) - acetonitrile buffer solution $\mathrm{pH}=2.92$ (4\%: 96\%) 0-6 min., (10\%: 90\%) 6-9 min., (20\%: 80\%) 9-15. (4\%: 96\%) 15-20 min. Injection volume - $20 \mu \mathrm{l}$. The speed 
of the mobile phase is $1,000 \mathrm{ml} / \mathrm{min}$. Column Eclipse XDB - C18. The detector is a DAD, wavelengths of 272, 292, 254, 297 and $360 \mathrm{~nm}$.

For quantitative analysis of the composition of macro- and microelements using inductively coupled plasma mass spectrometry (ICP/MS).

\section{DISCUSSION}

As can be seen from the diagram (Fig. 4), the vitamin content is very different from each other. The highest content is vitamin B9-2.67 $\mathrm{mg} / \mathrm{g}$, folic acid, which affects the immune system and the cardiovascular system. It also affects the motility of white blood cells and their ability to resist viral infections. In addition, folic acid is involved in the synthesis of amino acids and enzymes that help the liver and stomach digest food.

The content of pyridoxine (vitamin B6) -1.98 $\mathrm{mg} / \mathrm{g}$, promotes the absorption of protein and fat, as well as the conversion of tryptophan, an essential amino acid, to niacin. Helps prevent various nervous and skin disorders and relieves nausea. Promotes the correct synthesis of nucleic acids that prevent aging and acts as a natural diuretic.

Also the content of riboflavin (vitamin B2) is $1.15 \mathrm{mg} / \mathrm{g}$, which is a biologically active substance that plays an important role in maintaining human health as a colorizer. Riboflavin and its derivatives included in the coenzyme structure are involved in the most important redox enzymatic reactions. Vitamin B2 is also necessary for the formation of red blood cells, antibodies, for the regulation of growth and reproductive functions of the body. It is also important for healthy skin, nails, hair growth, and for the whole body, including thyroid function.

The content of ascorbic acid (vitamin C) -0.2 $\mathrm{mg} / \mathrm{g}$, is a powerful antioxidant and normalizes redox processes. It is used for hemorrhagic diathesis, capillary toxicosis, hemorrhagic stroke, bleeding (including nose, lung, uterine), infectious diseases, idiopathic methemoglobinemia, intoxications, alcoholic and infectious delirium, acute radiation sickness, post-transfusion complications (diseases, diseases chronic hepatitis and cirrhosis), gastrointestinal diseases (achilia, peptic ulcer, bleeding, enteritis, colitis), helminthiases, cholecystitis, sluggishly healing wounds, ulcers, burns, physical and mental overloads.

Another important ingredient in plant materials is the elements. The influence of micro and macro elements on the vital activity of animals and humans is being actively studied in biology for medical use. Any pathology, any deviation in the health of a biological organism is accompanied either by a deficiency of vital (essential) elements, or an excess of both essential and toxic trace elements. This imbalance of macro- and microelements has received the unifying name "microelements". Minerals are part of all body fluids and tissues. By regulating more than 50,000 biochemical processes, they are necessary for the functioning of the muscular, cardiovascular, immune, nervous and other systems; take part in the synthesis of vital compounds, metabolic processes, blood formation, digestion, neutralization of metabolic products; are part of enzymes, hormones (iodine as part of thyroxine and triiodothyronine, zinc - insulin and sex hormones), affect their activity.

The appearance in the literature of the term "heavy metals" was associated with the manifestation of the toxicity of some metals and their danger to living organisms. However, the group of "heavy" also included some trace elements, the vital necessity and a 
wide range of biological effects of which are irrefutably proven. Heavy metals are lead, cadmium, zinc, copper, nickel and chromium. In recent years, the important biological role of most "heavy" metals has been increasingly clearly confirmed. Numerous studies have established that the influence of metals is very diverse and depends on their content in the environment and the degree to which microorganisms, plants, animals and humans need them. The influence of "heavy" metals on living organisms is very diverse. This is due, firstly, to the chemical characteristics of metals, and secondly, the attitude of organisms to them and, thirdly, environmental conditions. Based on the above, it was interesting to study the content of heavy metals in the vegetative organs of a shepherd's bag plant. The data obtained are shown in table 4.
As can be seen from the data given in table 4, the content of heavy elements is relatively higher in the flowers and the smallest content of them falls on the stems. The content of copper and zinc in all organs prevails over other elements. It should be noted that a relatively higher content of lead and zinc is observed in the leaves of the studied plant. Figure 4 in a diagrammatic form shows the quantitative content of heavy metals in various organs of a shepherd's bag. As can be seen from diagram 4, the content of heavy elements is greater in the flowers and less in the stems, but at the same time, the ratio between the amounts of heavy metals remains. In a word, there is an equally proportional relationship between the analyzed elements.

\section{RESULT}

The quantitative content of water-soluble vitamins was determined by HPLC. All chromatograms are listed below (Fig 1. Fig 2.Fig 3)

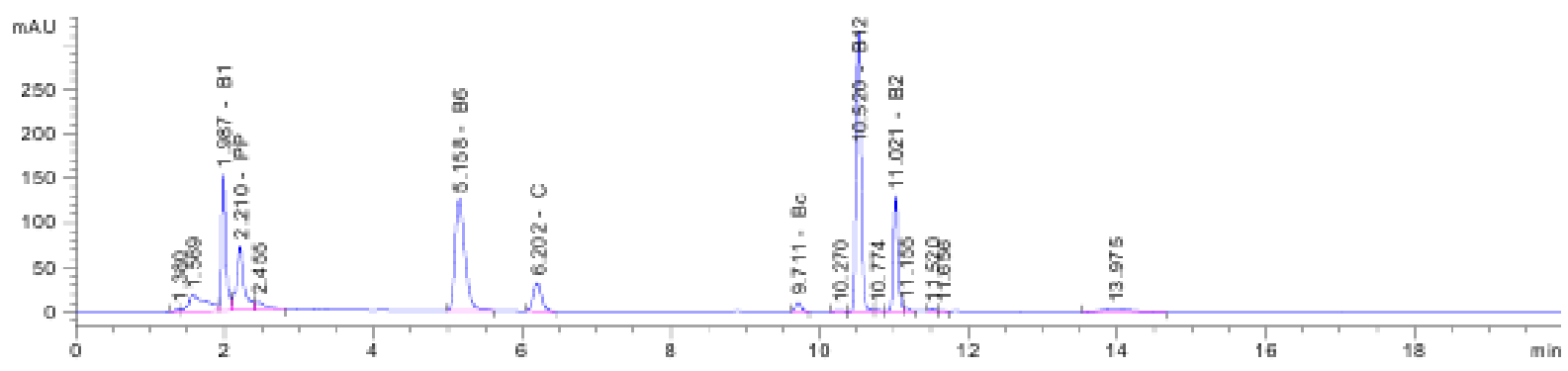

Fig 1.

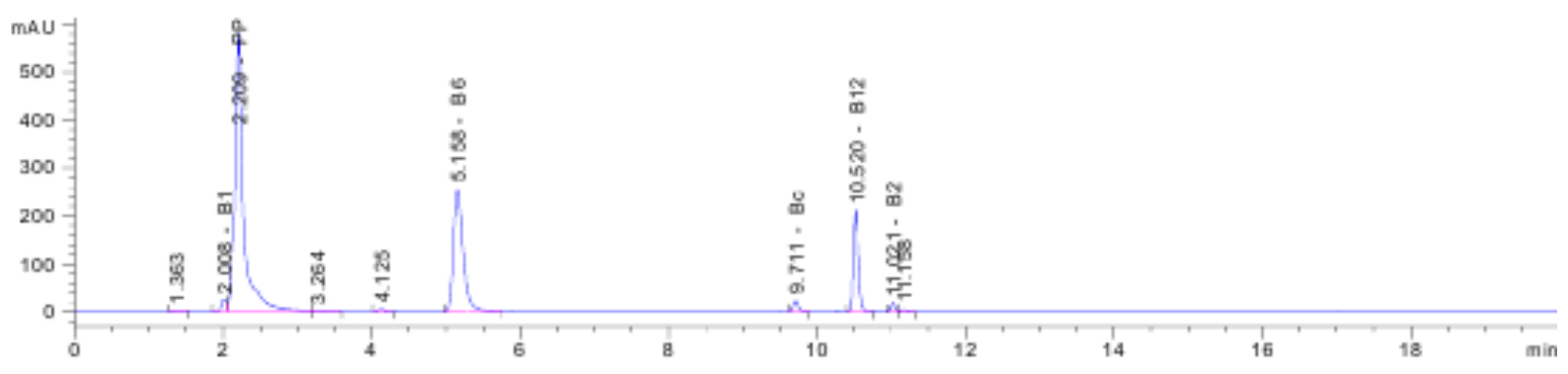


Fig 2.

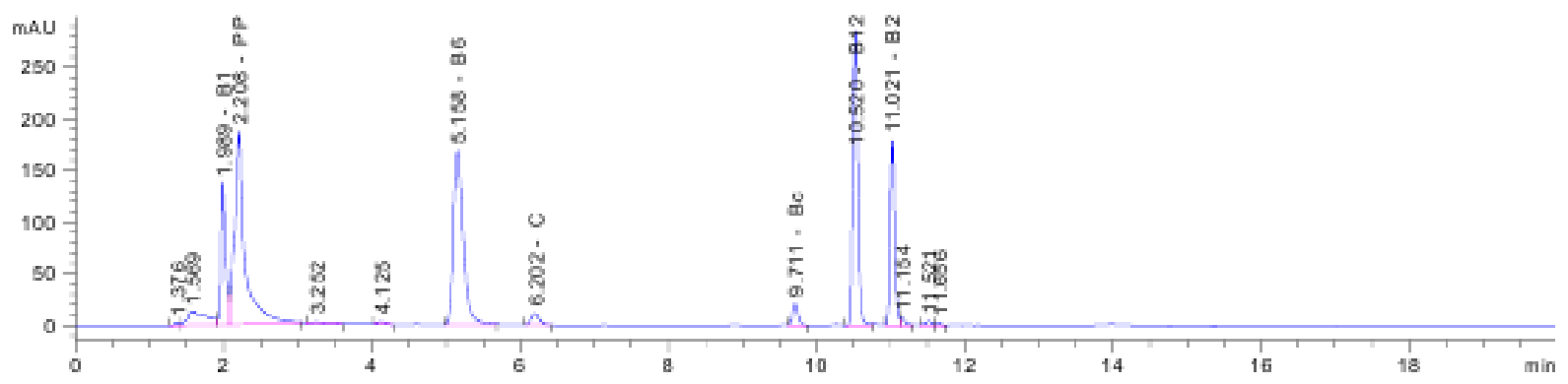

Fig 3.

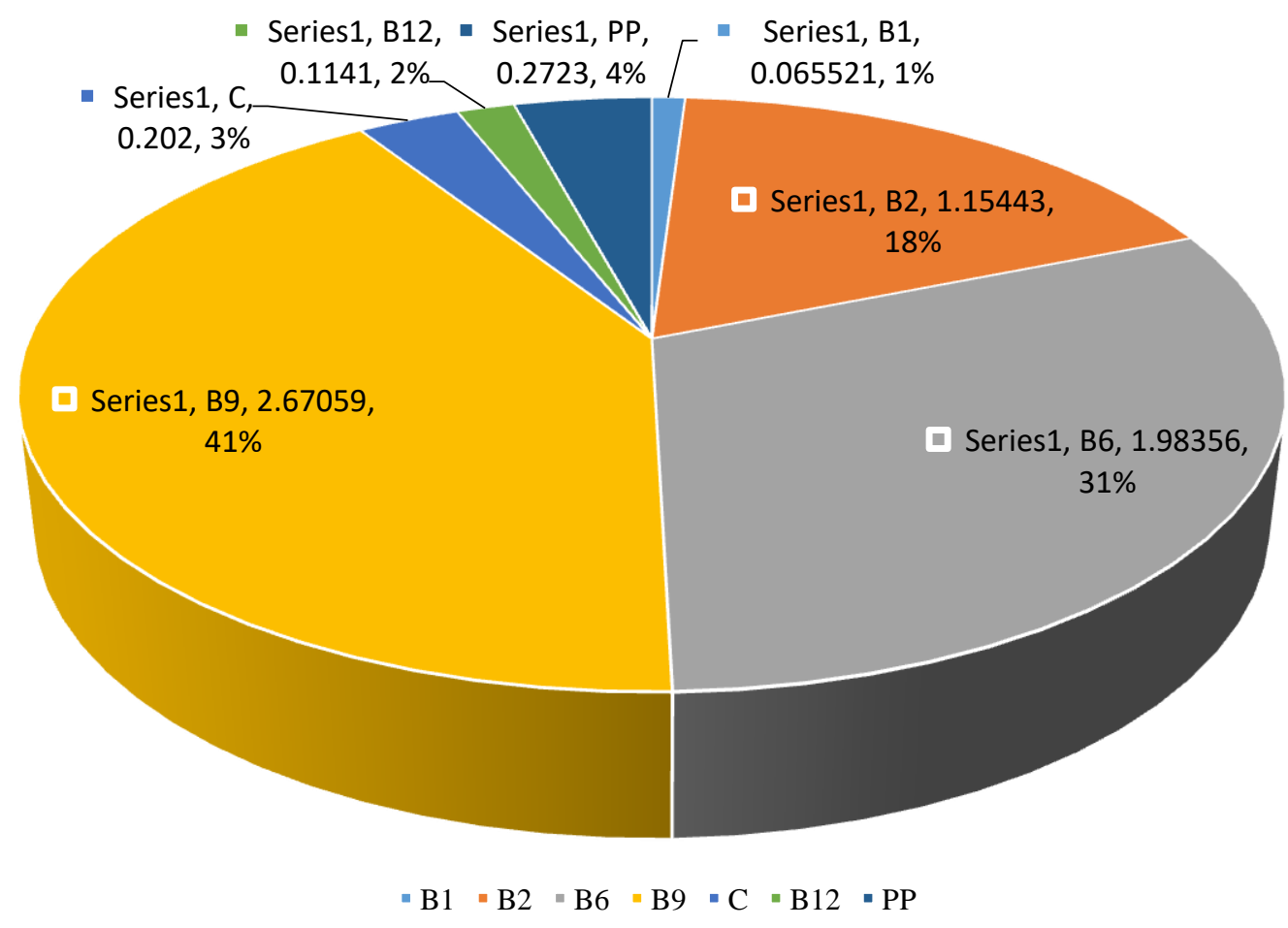

Fig 4. The content of water-soluble vitamins of the aerial part of the plant Capsella bursa (mg/g).

Based on the foregoing, it was interesting to study the macro-microelement composition of the vegetative organs of the plant Capsella bursa. The data obtained are shown in table 1 and in figure 2. 
Some macro- and microelements in the stems of the shepherd's purse plant

\begin{tabular}{|c|c|c|}
\hline \multirow{2}{*}{ № } & \multirow{2}{*}{ Elements } & Quantitative content \\
\cline { 3 - 3 } & & $\mathbf{~ m g / k g}$ \\
\hline 1 & $\mathrm{~K}$ & 29150,184 \\
\hline 2 & $\mathrm{Ca}$ & 4698,917 \\
\hline 3 & $\mathrm{Mg}$ & 1638,469 \\
\hline 4 & $\mathrm{Na}$ & 2165,375 \\
\hline 5 & $\mathrm{Fe}$ & 52,250 \\
\hline 6 & $\mathrm{Ba}$ & 45,341 \\
\hline 7 & $\mathrm{Mn}$ & 17,140 \\
\hline 8 & $\mathrm{Li}$ & 0 \\
\hline 9 & $\mathrm{Bi}$ & 0,003 \\
\hline 10 & $\mathrm{Ni}$ & 3,147 \\
\hline
\end{tabular}

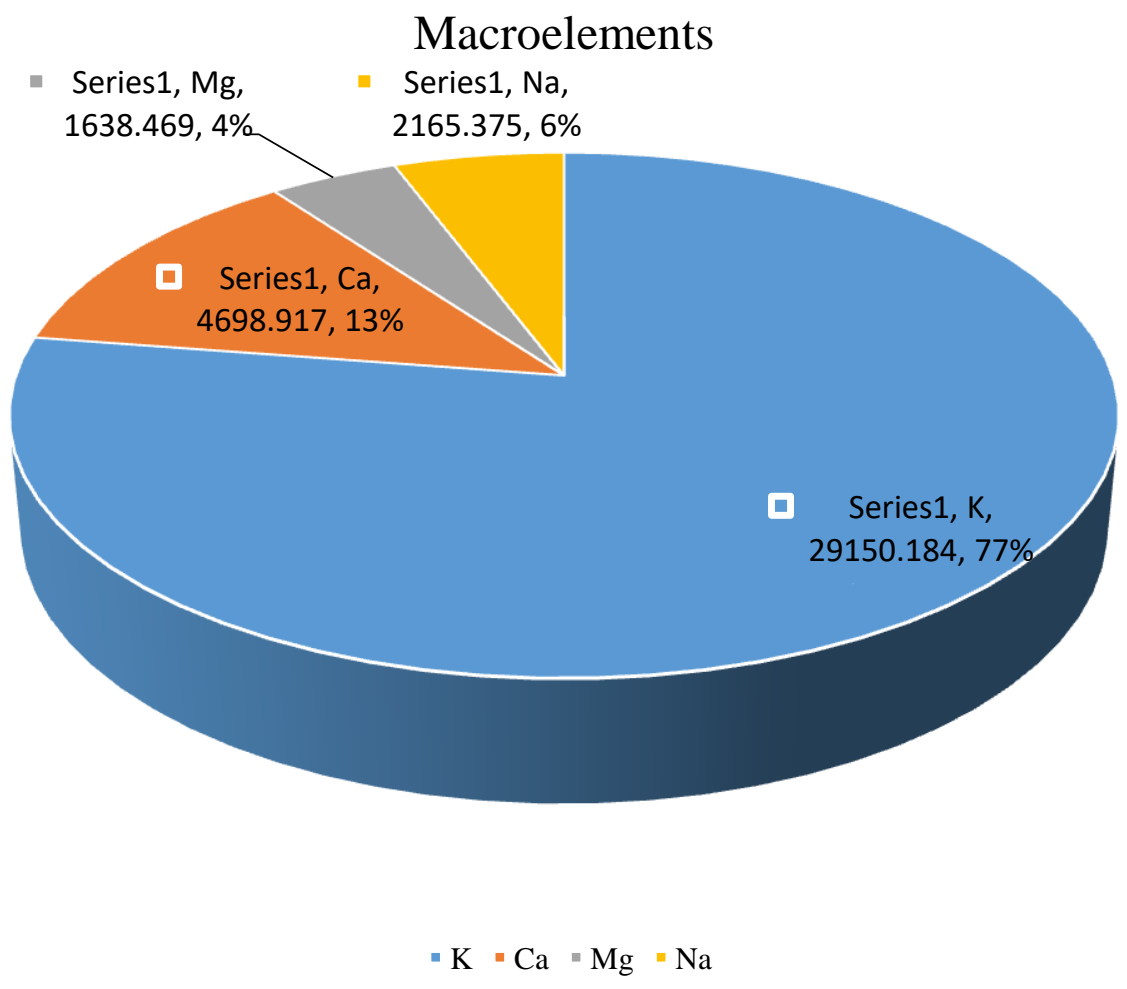




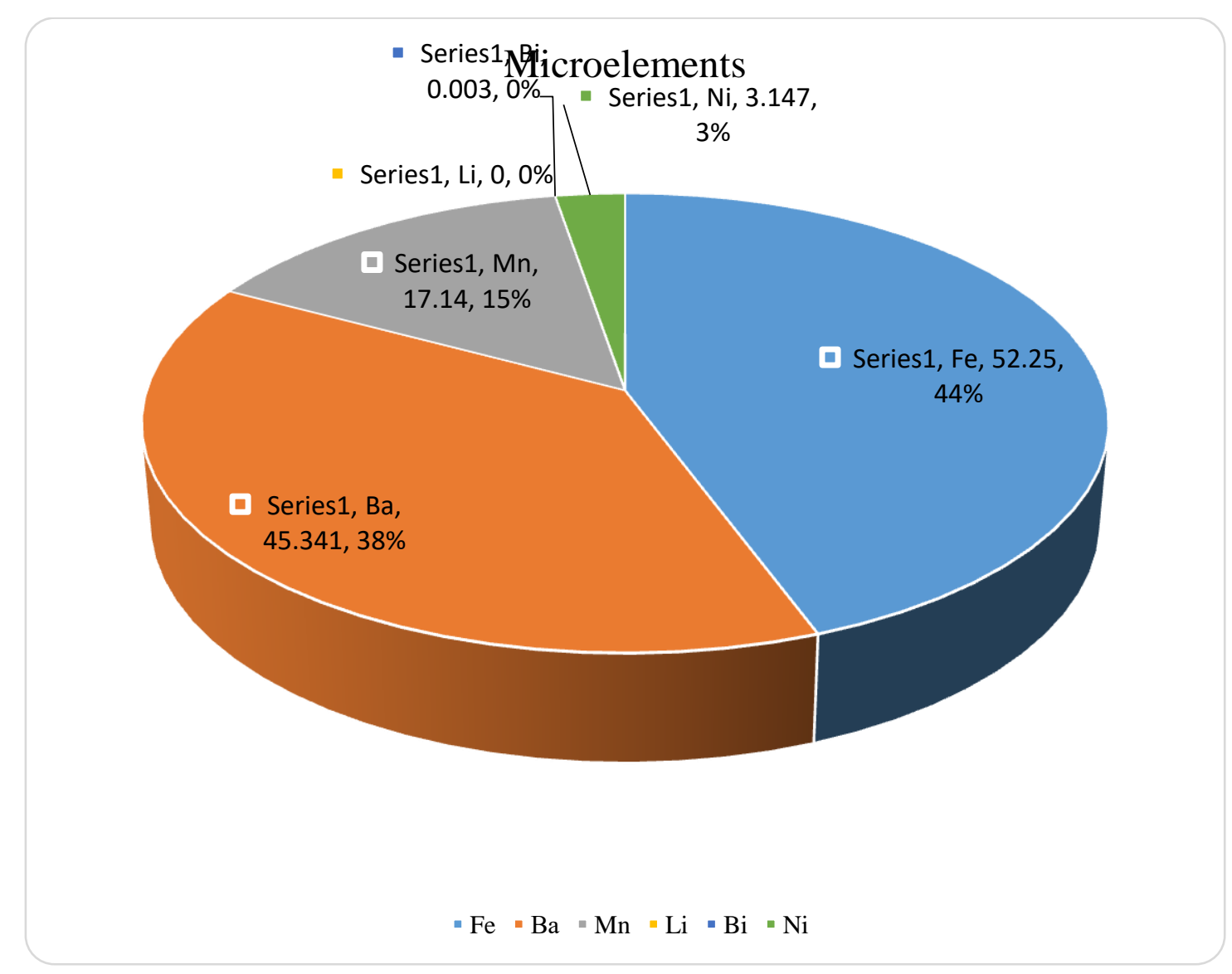

Fig. 1. The content of macro- and microelements in the stems of the shepherd's bag plant

The quantitative content of macroelements in the stems of a shepherd's bag plant is $3.6 \%$, of which potassium is $2.9 \%$, followed by calcium, sodium and magnesium $0.4 \%, 0.2 \%$ and $0.1 \%$, respectively. The content of trace elements differs from different types of vegetative organs of the plant. 
Some macro- and microelements in the leaves of the shepherd's bag plant

\begin{tabular}{|c|c|c|}
\hline \multirow{2}{*}{ № } & \multirow{2}{*}{ Elements } & Quantitative content \\
\cline { 3 - 3 } & & $\mathbf{~ m g / k g}$ \\
\hline 1 & $\mathrm{~K}$ & 56921,143 \\
\hline 2 & $\mathrm{Ca}$ & 21922,948 \\
\hline 3 & $\mathrm{Mg}$ & 6527,86 \\
\hline 4 & $\mathrm{Na}$ & 5813,528 \\
\hline 5 & $\mathrm{Fe}$ & 1062,917 \\
\hline 6 & $\mathrm{Ba}$ & 65,730 \\
\hline 7 & $\mathrm{Mn}$ & 77,957 \\
\hline 8 & $\mathrm{Li}$ & 1,436 \\
\hline 9 & $\mathrm{Bi}$ & 0,013 \\
\hline 10 & $\mathrm{Ni}$ & 6,368 \\
\hline
\end{tabular}

\section{Macroelements}

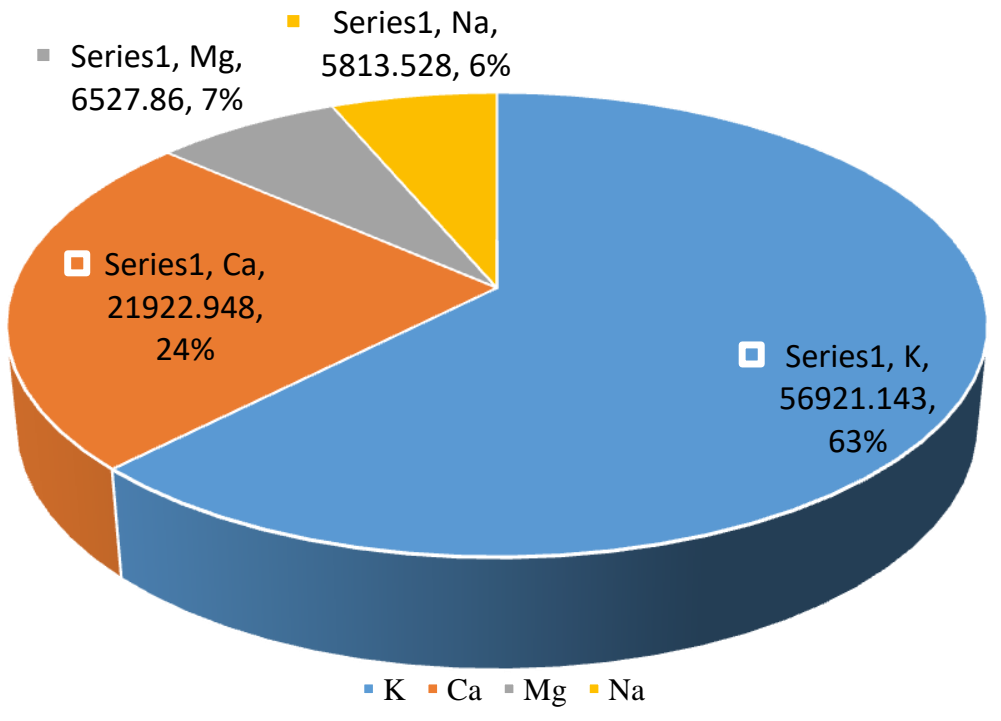




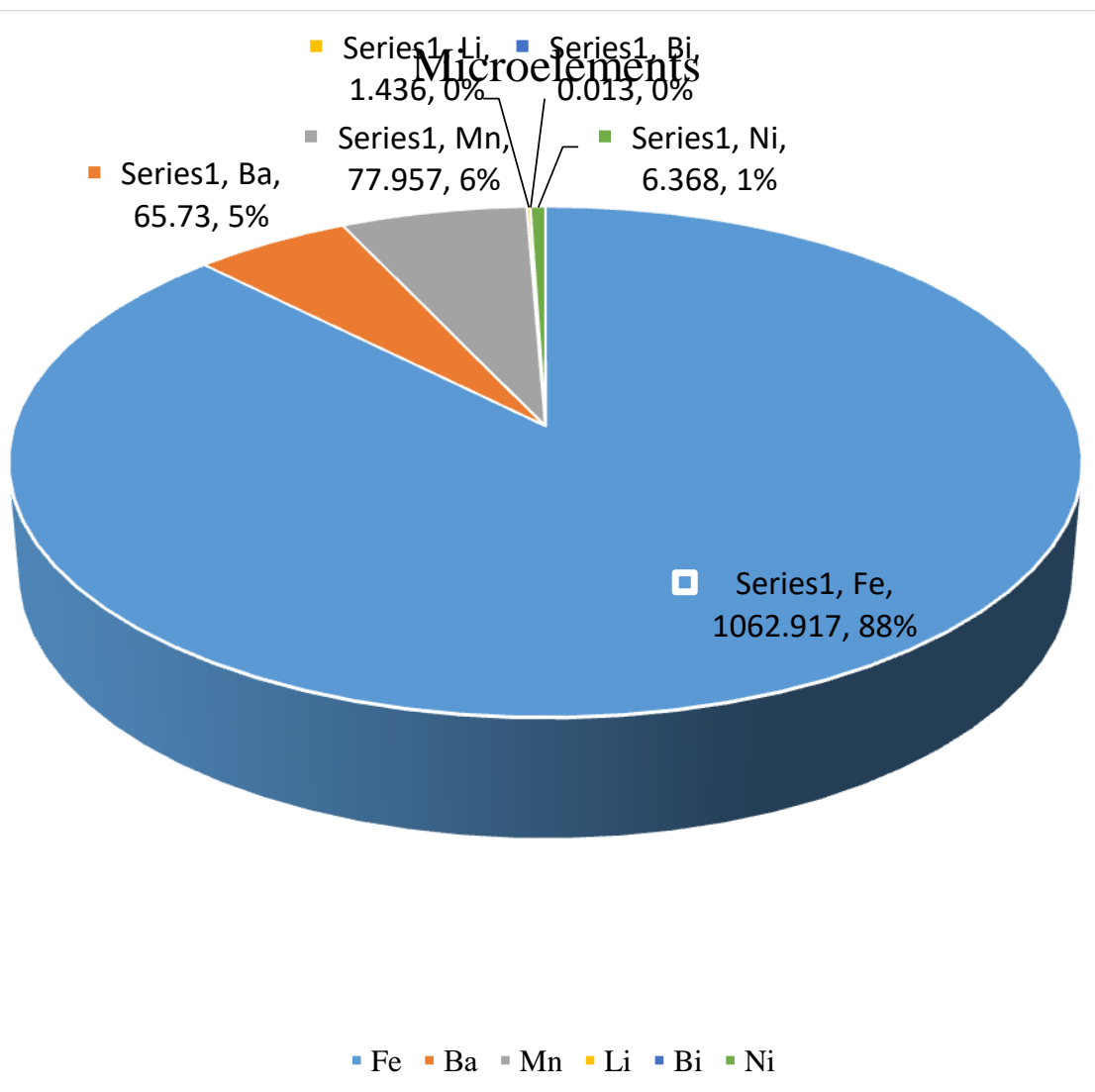

Fig. 2. The content of macro- and microelements in the leaves of the plant shepherd's bag $(\mathrm{mg} / \mathrm{kg})$

The quantitative content of macronutrients in the leaves of the shepherd's bag plant reaches $8 \%$, and of these: potassium $5.6 \%$, then calcium, magnesium and sodium, $2.1 \%, 0.6 \%$ and $0.5 \%$, respectively. 
Table №3

Some macro- and microelements in the composition of the flowers of the shepherd's bag plant.

\begin{tabular}{|c|c|c|}
\hline \multirow{2}{*}{ № } & \multirow{2}{*}{ Elements } & Quantitative content \\
\cline { 3 - 3 } & & $\mathbf{m g} / \mathbf{k g}$ \\
\hline 1 & $\mathrm{~K}$ & 33637,542 \\
\hline 2 & $\mathrm{Ca}$ & 6280,233 \\
\hline 3 & $\mathrm{Mg}$ & 4525,155 \\
\hline 4 & $\mathrm{Na}$ & 2009,956 \\
\hline 5 & $\mathrm{Fe}$ & 459,340 \\
\hline 6 & $\mathrm{Ba}$ & 22,268 \\
\hline 7 & $\mathrm{Mn}$ & 64,001 \\
\hline 8 & $\mathrm{Li}$ & 0,382 \\
\hline 9 & $\mathrm{Bi}$ & 0,008 \\
\hline 10 & $\mathrm{Ni}$ & 17,319 \\
\hline
\end{tabular}

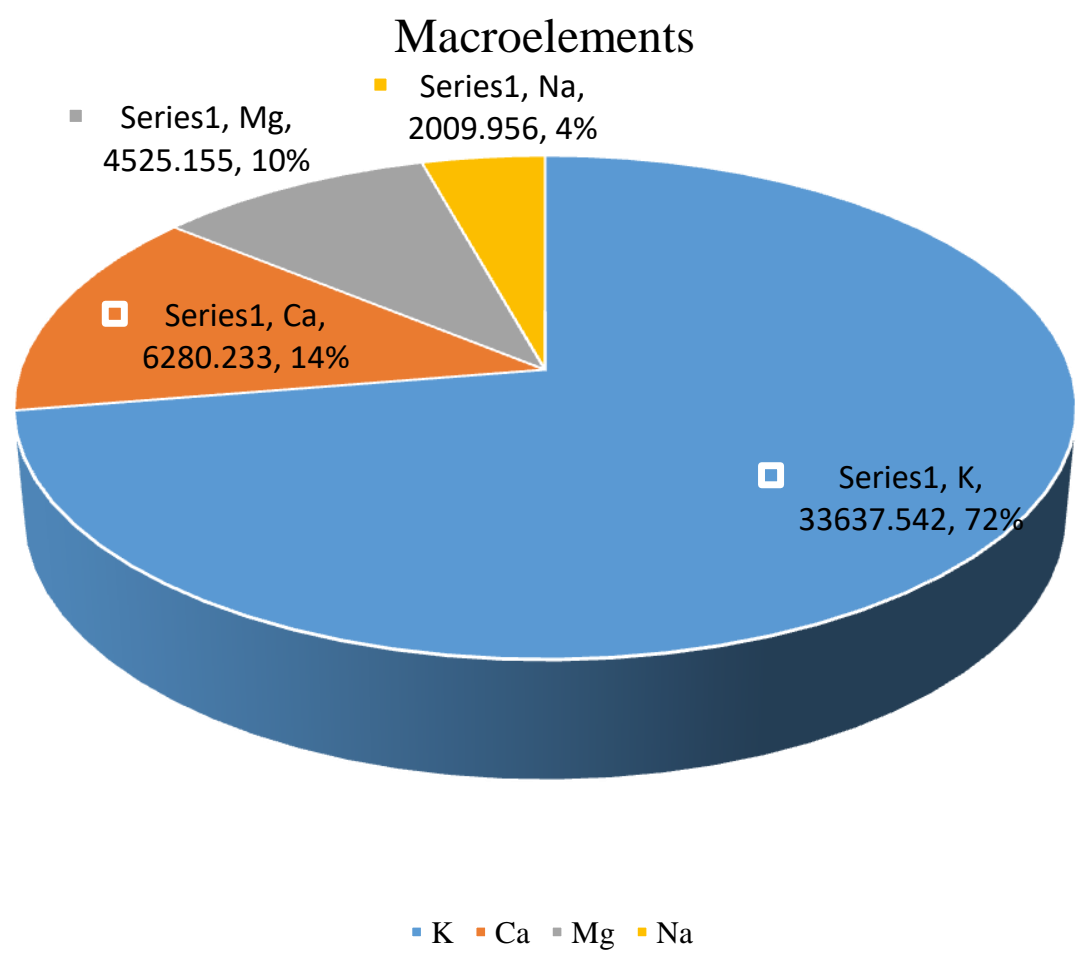




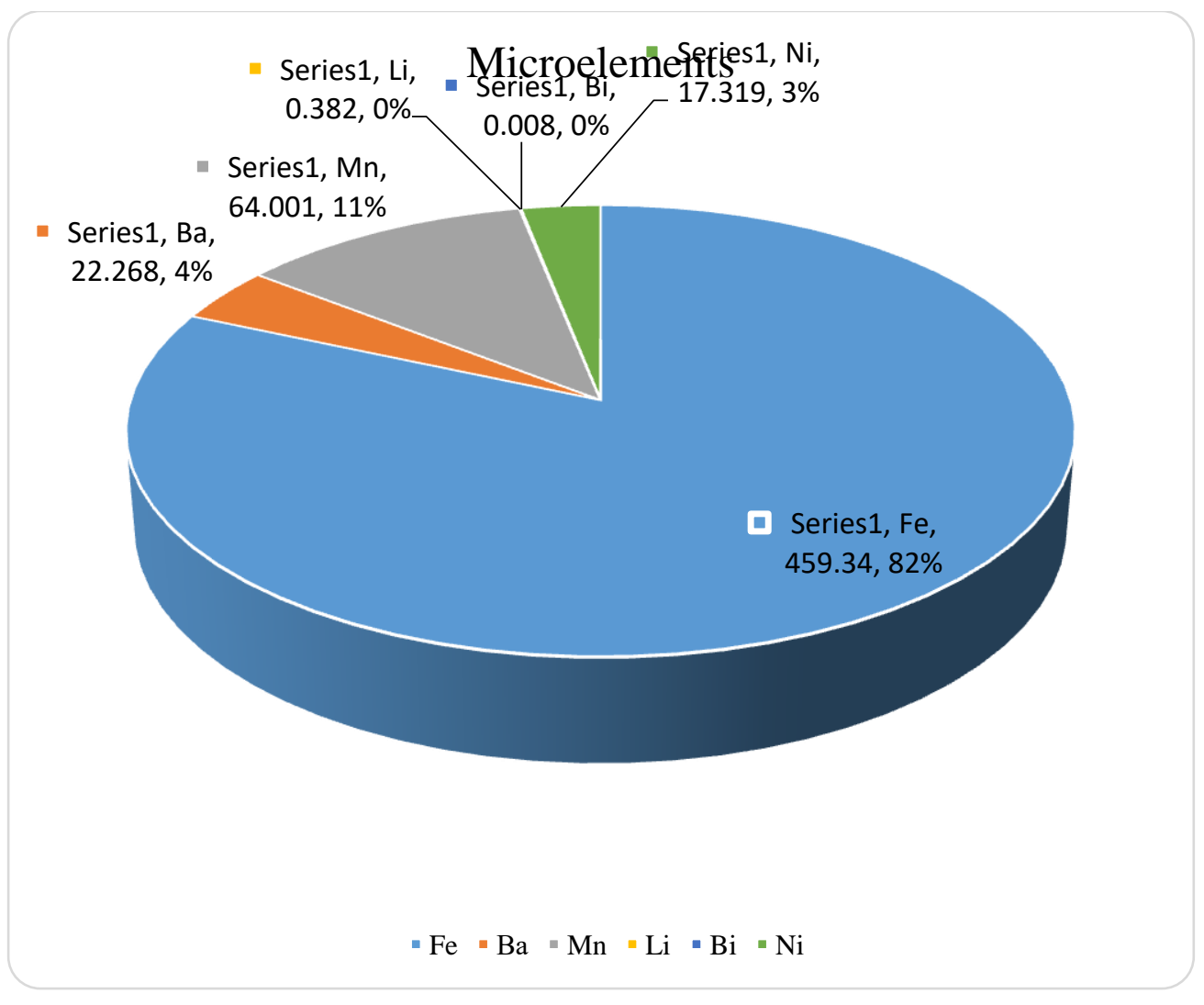

Fig. 3. The content of macro- and microelements in the composition of the flowers of a shepherd's bag plant.(mg/kg)

As can be seen from the data in table No. 3 and figure 3, the content of macronutrients in the flowers of the plant reaches $4.5 \%$. Of Table №4 these, potassium is $3.3 \%$, the remaining elements are calcium, magnesium and sodium $0.6 \%, 0.4 \%$ and $0.2 \%$, respectively.

Some heavy metals in the stems, leaves and flowers of a shepherd's purse plant

\begin{tabular}{|c|l|c|c|c|}
\hline \multirow{2}{*}{ № } & \multirow{2}{*}{ Elements } & \multicolumn{3}{|c|}{ Quantitative content, mg/kg } \\
\cline { 3 - 5 } & & The stalks & Leaves & Flowers \\
\hline 1 & $\mathrm{Cu}$ & 8,180 & 12,168 & 16,490 \\
\hline 2 & $\mathrm{~Pb}$ & 1,548 & 4,907 & 1,636 \\
\hline 3 & $\mathrm{Cd}$ & 0,093 & 0,204 & 0,077 \\
\hline 4 & $\mathrm{As}$ & 0,237 & 0,968 & 0,350 \\
\hline 5 & $\mathrm{Zn}$ & 15,129 & 27,757 & 65,712 \\
\hline 6 & $\mathrm{Hg}$ & 0 & 0 & 0 \\
\hline
\end{tabular}



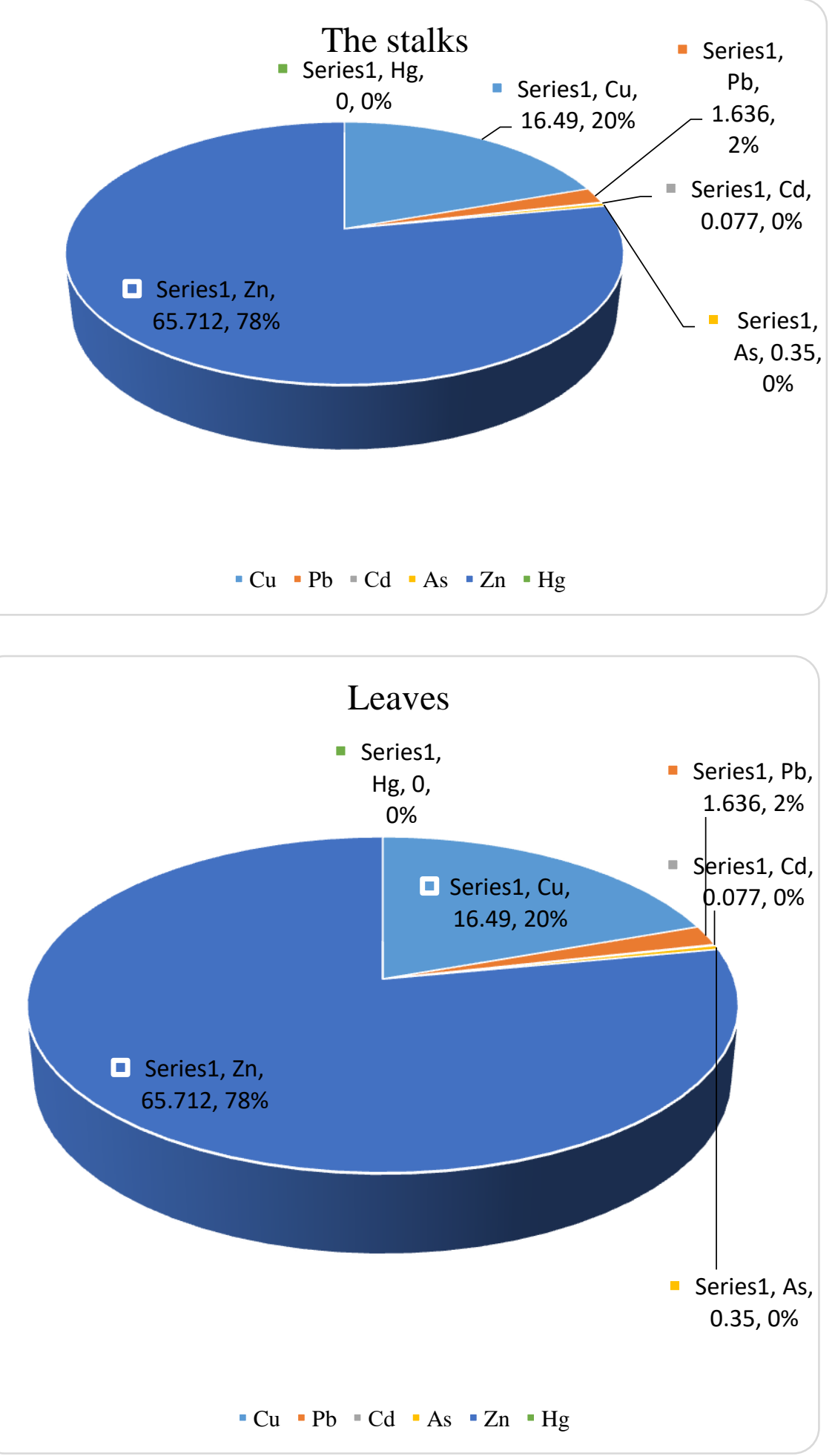


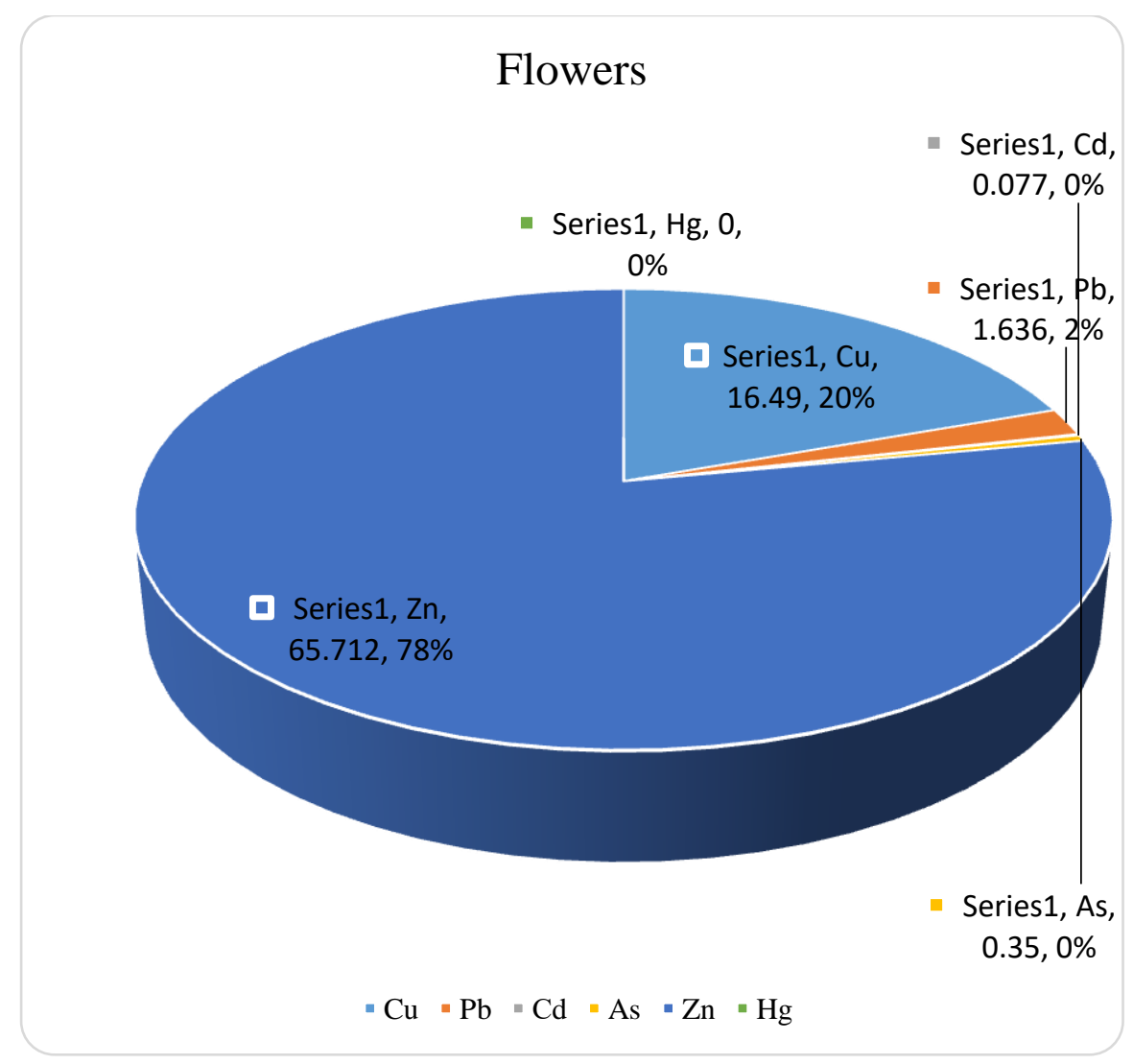

Fig. 4. The content of heavy metals in the stems, leaves and flowers of a shepherd's purse

$$
\text { plant.(mg/ kg) }
$$

\section{CONCLUSION}

Thus, as a result of studies to determine the content of water-soluble vitamins, macro- and microelements, as well as salts of heavy metals, we can draw the following conclusions.

- The quantitative content of water-soluble vitamins of the aerial part of the plant Capsella bursa was determined by HPLC.

- Using the ICP-MS method, the quantitative content of vital macro- and microelements in the various vegetative organs of the Capsella bursa plant was determined. It is shown that macroelements are relatively rich in leaves and flowers of plants. The highest salt content of heavy metals is observed in the flowers of the plant, but within normal limits.

- The data obtained show that the aerial part of the plant Capsella bursa can be used as a valuable source of vitamins and nutrients.

\section{REFERENCES}

1. Hossein Kamali,Tooba Ahmadzadeh sani, Peyman Feyzi, Ameneh Mohammadi. Chemical composition and antioxidant activity from Essential oil of Capsella bursapastoris. International Journal of 
PharmTech Research. 2015. Vol.8, №.8, pp 1-4,

2. Lovkova M.Ya., Rabinovich A.M., at al. Why are plants treated M., Science 1990. P.290

3. Al-Snafi A.E. The chemical constituents and pharmacological effects of Capsella bursapastoris-A review-International Journal of Pharmacology and toxicology 2015, 5, 2, pp. 76-81.

4. Kolesnik Yu.S., Kislichenko V.S., Kuznetsova V.Yu. The study of flavonoids grass shepherd's purse - Ukrainian Journal of Clinical and Laboratory Medicine 2011, 6, 3, pp. 122-123.

5. Sklyarevskaya N.V., Pakhomova L.A. Determination of flavonoids in the grass of a shepherd's purse: development of a technique and its validation - Pharmacy 2017, 66, 4, pp.20-24.

6. Cha J.M., Suh W.S., Lee T.H., Subedi L., Kim S.Y., Lee K.R. Phenolic Glycosides from Capsella bursa-pastoris (L.) Medik and Their Anti-Inflammatory Activity Molecules. 2017. Jun 20, 22(6). pii: E1023. doi: 10.3390/molecules p. 22061023.

7. Tseslovskaya E.P., Burd G.A. The content of the sum of phenolic compounds and flavonoids in samples of Capsella bursapastoris - Actual environmental problems A collection of scientific articles based on the materials of the XII International scientific and practical conference Grodno 2017, pp. 124-125.

8. Trineeva O.V., Slivkin A.I., Study of the trace element composition of dioica nettle leaves. Medicine series. Pharmacy 2015. №. 22 (219). Issue 32. P.169-170.

9. Ibraeva L. S., Sapakova A. K., Nurekenova A. N., Ontagarova D. R., Iminova D. E. Determination of macroelements in some medicinal plants by mass spectrometry /I Young Scientist. - 2017. - №. 6.1. pp. 26-29.
10. Shelemetyeva O.V, "Determination of vitamins by high performance liquid chromatography in premixes, dietary supplements and food products" Abstract of dissertation for the degree of candidate of chemical sciences. Tomsk - 2009. 